\title{
Keyness and Collocation Distinctions in How Latter-day Saint Communities Relate to God: Implications for Mental Health Professionals
}

\author{
Paul T. Callister ${ }^{1}$ (D) https://orcid.org/0000-0002-7214-3938 \\ Cass Dykeman ${ }^{1}$ (D) https://orcid.org/0000-0001-7708-1409 \\ ${ }^{1}$ Oregon State University
}

This in the authors' preprint of a manuscript being prepared for submission to a peer reviewed journal. Comments are invited and can be directed to the first author at callistp@oregonstate.edu

\begin{abstract}
Multicultural competence includes understanding how spirituality informs client worldview. This corpus linguistics study examines the worldview of members of The Church of Jesus Christ of Latter-day Saints through analysis of the Book of Mormon as a sacred text. Keywords of the Book of Mormon text are identified by using the Hebrew Bible and New Testament as reference corpuses, and the Book of Mormon is used as a reference corpus to identify biblical keywords as well. Collocates of deity within the Book of Mormon text are identified and examined. Limitations and implications for research and practice are discussed.

Keywords: multiculturalism, CACREP, spirituality, God, deity, corpus linguistics, keyness, collocation, Book of Mormon, counseling, worldview, religion, Latter-day Saints, theistic values
\end{abstract}

\section{Introduction}

Nearly three-quarters of the U.S. population identify as religious (Pew Research Center, 2019). While such an identity is commonplace, the place of religion and spirituality in mental health treatment has been long debated. More recently, ethical standards in the helping professions have pointed to an imperative for practitioners to not ignore this aspect of identity. However, skills and knowledge among practitioners lag. Understanding the relationship between spirituality and mental health is fundamental to providing effective counseling of clients who identify as religious.

The Council for Accreditation of Counseling and Related Educational Programs (CACREP , 2016) provides an example of a clear knowledge and skills imperative. The training standard 2.F.2.g specifies that "the impact of spiritual beliefs on clients' and counselors' worldview" (p. 9) are foundational knowledge required as part of social and cultural diversity. Ethical and accreditation statements from allied professions (e.g., social work, marriage and family therapy, psychology) contain similar language. For example, the social work ethical code 1.05.c states "Social workers should obtain education about and seek to understand the nature of social diversity and oppression with respect to race, ethnicity, national origin, color, sex, sexual orientation, gender identity or expression, 
age, marital status, political belief, religion, immigration status, and mental or physical ability" (National Association of Social Workers, 2017, p. 1).

One religious community within the U.S. are members of The Church of Jesus Christ of Latter-day Saints. This community represents $2 \%$ of the U.S. population (Pew Research Center, 2019), or 6.7 million people (The Church of Jesus Christ of Latter-day Saints, n.d.-a). Despite the size and geographic spread of this community, little knowledge exists in the counselor education literature on the community. The aim of the present study is to address this gap with the goal of greater adherence to the aforementioned training and ethical standards. Increasing multicultural competence of counselors who work with Latter-day Saint clients could disrupt current practice with this population by facilitating effective practice based on attunement with these clients and their religious and spiritual worldview.

In a review of the literature on the relationship with members of The Church of Jesus Christ of Latter-day Saints to deity and of distinctions of the Book of Mormon compared to other sacred texts, five key issues emerged. These key issues were: (a) key definitions, (b) the relationship of view of deity and worldview, (c) the relationship of language and worldview, (d) the relationship of counselor attunement to client worldview and effective counseling, (e) research on keyness, (f) research on collocations of deity, and (g) sacred canonical considerations. After these issues are discussed, the research questions developed to guide the present study will be enumerated.

There are three key terms that need to be defined in order for the objectives of this study to be clear. These terms are (a) deity, (b) scripture, and (c) worldview. The term deity refers to a god or goddess in polytheistic religion and to the creator and supreme being in monotheistic religions, such as Christianity. In the Hebrew Bible and New Testament, God refers to the creator of heavens and earth. In the biblical text, God is presented as a personal God, who is involved in Israel and the world (Bullock, 1997). The bible dictionary that accompanies the canonized scriptures of The Church of Jesus Christ of Latter-day Saints says God is the supreme governor of the universe and the father of mankind. In addition, Latter-day Saint cannon refers to the Godhead, which represents a council of three distinct beings, God the Father, his Son Jesus Christ, and the Holy Ghost (The Church of Jesus Christ of Latter-day Saints, n.d.-b).

The term scripture means the same thing across the three spiritual traditions addressed in this paper. Scripture is the sacred writings of a religion. It comes from the word scribere, meaning writing or to write, and denotes writings that are sacred and inspired. Within religious communities it is seen as being inspired by God and as a guide for daily living. Within the Latter-day Saint communities, scripture is viewed as being inspired by the Holy Ghost, and being the will, mind, word, and voice of God, and "the power of God unto salvation" (Smith, 1835, p. 73). In the case of Christianity, it is the sacred writings contained in the Holy Bible. For members of The Church of Jesus Christ of Latter-day Saints, scripture includes the Holy Bible as well as the Book of Mormon. As such, while the exact sacred canon differs among Christian traditions, the concept of 
scripture does not. Like the concept of scripture, the concept of worldview is key to the present research study.

The term worldview defines a particular way of viewing life and existence. The Oxford English Dictionary defined worldview as "a set of fundamental beliefs, values, etc., determining or constituting a comprehensive outlook on the world" (Oxford University Press, 2020). Such a definition is supported by the work of Sigmund Freud (1989), who defined the related word weltanschauung (literally, a perception of the world) as "an intellectual construction which solves all the problems of our existence uniformly on the basis of one overriding hypothesis, which, accordingly, leaves no question unanswered and in which everything that interests us finds its fixed place" (pp. 195-196).

Deistic beliefs are known influencers of worldview. Influential theologian Paul Tillich (1957) defined God as that which concerns man ultimately showing the intersection between God and worldview in modern thought. Joseph Smith, the founder of The Church of Jesus Christ of Latter-day Saints, taught about the importance of a correct view of God. He taught that "the great parent of the universe looks upon the whole of the human family with a fatherly care and paternal regard" (Smith, 1842, p. 759) and that "if men do not comprehend the character of God, they do not comprehend themselves" (Richards, 1844, p. 67). As such, members of The Church of Jesus Christ of Latter-day Saints form a worldview of God as a "Heavenly Father" who is a personal and loving father, and their relationship to him being that of "children of God". Thus, for Latter-day Saints, the view of God is tied to worldview.

Additionally, worldview is directly tied to language. The Prussian philologist Wilhelm von Humboldt (1836/2000) originated the idea that language and worldview are inextricable. According to von Humboldt, worldview is embedded in language, and through language humans are able to make use of and develop their mental processes to make sense of reality. He believed that this is true in all languages and among all groups of people. Thus, examination of language can help in understanding the worldview of groups and individuals. In addition, understanding language and worldview can facilitate effective multicultural counseling.

To provide effective counseling, mental health professionals need to possess a robust understanding of a client's worldview. CACREP (2016) mandates that understanding the spiritual aspects of a client's worldview is a part of social and diversity competence. Sue and Sue (2013) also listed understanding the worldview of clients as one of the core cultural competencies. Focusing on the worldview of the individual client allows the therapy to be personalized. Personally-relevant interventions increase client engagement and increase effectiveness for diverse groups (Hall et al., 2020). Understanding of worldview is directly linked to therapist-client attunement and effective therapy. Also, examination of language can help promote understanding of diverse perspectives. 
Keyness refers to words that occur with unusual frequency in a given text by comparison with a reference corpus. It is closely related to the notion of aboutness, that is, the understanding of main concepts, topics, and attitudes presented or discussed in a text (Gabrielatos, 2018). Keyness has been used to study sacred and other texts. For example, Wang (2014) used keyness to examine the use of repetition in the biblical book of Matthew, and recommended further use of keyness to understand biblical texts. In addition, collocation is an additional corpus linguistic tool which may be used to examine meaning of texts.

Collocation is a linguistic tool that adds understanding to the meaning of words. Indeed, eminent linguist J. R. Firth (1957) noted that "you shall know a word by the company it keeps" (p. 6). In general, collocations can be defined as "combinations of words that habitually co-occur in texts and corpora" (Brezina, 2018, p. 67). After eliminating stopwords, the five most frequent collocations of God in the King James Version (KJV) are LORD, God, Israel, man, and house (Callister, 2020). Biblical collocation gives meaning to how this text represents deity and serves as a basis for comparison with other sacred texts.

The sacred canon of The Church of Jesus Christ of Latter-day Saints consists of the Holy Bible, the Book of Mormon, the Doctrine and Covenants, and the Pearl of Great Price. In this study I will examine intercanon distinctions, whereas further research may look at sacred text outside of the Latter-day Saint canon (e.g., the Quran, the Vedas, the Tripitaka). Because the KJV of the Holy Bible was used at the time that the Book of Mormon was first published in 1830 and remains the standard version for this community, the KJV will be used. According to reception theory (Knight, 2010), selection of this English language version allows comparison with the biblical texts that have been received and thus influenced Latter-day Saint worldview formation. As well, the early modern and late middle English language of both the KJV and the Book of Mormon profitably support their comparison.

Given the aforementioned and the goal to understand distinctiveness of the Latter-day Saint community's worldview, five research questions were developed:

RQ1: What word usage distinguishes the Book of Mormon from the New Testament?

RQ2: What word usage distinguishes the New Testament from the Book of Mormon?

RQ3: What word usage distinguishes the Book of Mormon from the Hebrew Bible?

RQ4: What word usage distinguishes the Hebrew Bible from the Book of Mormon?

RQ5: In the Book of Mormon, what are the words most closely related to the proper noun "God"? 


\section{Method}

\section{Design}

The present research study used a corpus linguistics design (Weisser, 2016). There were four variables: subcorpus, keyness, node, and collocates of the node. The corpus was composed of three subcorpuses that represent influential sacred texts in the Judeo-Christian tradition. These texts were: the Hebrew Bible (KJV), the New Testament (KJV), and The Book of Mormon: The Earliest Text (Skousen, 2009). The type of measure varied by variable: (a) corpus was nominal, (b) keyness was continuous, (c) node was nominal, and (d) collocate was nominal. The unit of analysis was words.

For RQs 1-4, the log-likelihood ratio test (i.e., $\mathrm{G}^{2}$ test) was employed to examine keyness (Brezina, 2018; Dunning, 1993). G*Power does not contain analysis for the $\mathrm{G}^{2}$ test (Faul et al., 2009). However, since the $\mathrm{G}^{2}$ test is a derivation of the $\chi 2$ test, this test was used as a proxy. A medium effect size for the $\chi 2$ test was inputted (Cohen, 1988). The input parameters were: (a) test family- $\chi 2$ tests; (b) statistical test- goodness-of-fit tests: contingency tables; (c) type of power analysis - a priori: compute required sample size - given $\alpha$, power, and effect size; (d) $\mathrm{w}=0.30$; (e) power $(1-\beta$ error probability $)=$ $0.90 ;$ (f) $\alpha=.001$; and (g) degrees of freedom (Df) $=1$. The $\mathrm{G}^{*}$ Power 3.1 output suggested a sample size of 233 with an actual power of 0.90 .

RQ5 involved exploring relationships between words. Since G*Power doesn't offer a mutual information option, the calculation for a point biserial correlation was selected as a proxy. The average Cohen's d from a study of impact of collocation manipulation upon learning was employed as the effect size input ( $\mathrm{d}=1.325$; Boers et al., 2017). This average Cohen's d was then transformed into the effect size appropriate for a point biserial correlation: $|\mathrm{r}|$ (Ellis, 2009). The input parameters were: (a) test family $=\mathrm{t}$ tests; (b) statistical test $=$ correlation: point biserial model; (c) type of power analysis $=$

a priori: compute required sample size - given $\alpha$, power, and effect size; (d) effect size $|\mathrm{r}|$ $=0.5522 ; €$ power $(1-\beta$ err probability $)=0.90 ;(\mathrm{f}) \alpha=.05$; and $(\mathrm{g})$ tails $=2$. The $\mathrm{G}^{*}$ Power 3.1 output included a sample size of 27 and an actual power of 0.91 .

\section{Corpus}

\section{Register, Sources, and Scope}

The register is sacred texts. The sources for the corpus were the KJV of the Holy Bible (1611/2004) and The Book of Mormon: The Earliest Text (Skousen, 2009). The KJV was used for both the Hebrew Bible as well as for the New Testament. The earliest text version of the Book of Mormon was selected due to its removal of printing and scribal errors, as well as the modernization of the language that followed the original 1830 printing. For the Hebrew Bible and the New Testament, the translation used was the KJV. For the whole corpus, the token (word count) and type counts (unique words) were 1,060,020 and 14,068, respectively. The token and type counts for the subcorpuses were: 
Hebrew Bible (609,424 and 10,751), New Testament (180,585 and 6,006), Book of Mormon (270,011 and 5,616).

\section{Preprocessing}

The KJV $(1611,2004)$ Hebrew Bible and New Testament in .txt format were drawn from the Project Gutenberg website. Yale University Press and the editor gave permission to receive and use the text files of The Book of Mormon: The Earliest Text (Skousen, 2009) for this dissertation study. All of these files were in ASCII format, and there were no non-ASCII characters. The text was processed by removing punctuation, numbers, and white space. Then a document-term matrix was generated for application with keyness but not collocation. Word stemming was not applied, and stop words were not removed. For the collocation analysis, the stop words were filtered out after analysis.

\section{Measures}

\section{Word Node}

The node is the central word to which the collocates are associated. For the purpose of uniformity and ease of comparison, a single deity nodal word was chosen. The single node word was "God", which is capitalized and in the singular form. Keyness

The keyness parameters were: maximum wanted $=100$; minimum frequency $=5$; minimum $\log$ ratio $=1.5 ;$ minimum Bayesian information criterion $(\mathrm{BIC})$ scores $=2.5$; and minimum p-value $=0.001$. Stop words were excluded from the top 100 words.

\section{Collocation}

The collocation parameters were as follow: statistic name $=\mathrm{MI}^{2}$, statistic cut-off value $=3$, left and right $\operatorname{span}=8$, minimum collocate frequency $=5$, minimum occurrence frequency $=100$.

\section{Apparatus}

The software program used for analyses was R Studio. Quanteda (Benoit, Watanabe, Wang, Nulty et al., 2021) and quanteda.textstats (Benoit, Watanabe, Wang, Lua et al., 2021) were the R packages used for both keyness and collocation. Text was processed using the "tm" package (Feinerer, 2011).

\section{Statistical Analysis}

The first four research questions compared the proportions for each token in the corpus of interest and a reference corpus. As such, the proper statistical analysis is the $\log$-likelihood $\left(\mathrm{G}^{2}\right.$; Brezina, 2018). The effect size used was BIC. The BIC strength 
descriptors employed were those of Neath and Cavanaugh (2012). For the fifth research question, the measure of association used was the square of mutual information $\left(\mathrm{MI}^{2}\right.$; Brezina, 2018).

\section{Results}

RQs 1-4 involve keyness analysis between study and reference corpuses. The results for these analyses can be viewed in Table 1. RQ5 examined the words associated with the node word "God". The collocates results can be found in Table 2. Complete results can be reviewed on this research project's Open Science Foundation website (https://osf.io/x2hev/).

\section{Discussion}

The aim of this study was to explore the spiritual worldview of members of The Church of Jesus Christ of Latter-day Saints and related Latter-day Saint communities through corpus linguistic analysis of the Book of Mormon as a sacred text of this community. The first four research questions examined keywords of the Book of Mormon compared to the New Testament (RQ1) and Hebrew Bible (RQ3) and the keywords of the New Testament (RQ2) and the Hebrew Bible (RQ4) to the Book of Mormon. The fifth research question identified the words that most commonly co-occur with the proper noun "God" in the Book of Mormon.

RQ1 examined the Book of Mormon compared to the New Testament. The top keyword "pass" comes from a Hebrew word wayehi which may be translated as "and it came to pass", which occurs frequently in the Book of Mormon, and which is used to connect two ideas or events (Parry, 1992). The text itself refers to its Reformed Egyptian and Hebrew origins (e.g., Mormon 9:32-33), and this phrase has been identified as commonly occurring in Hebrew Bible narratives and in narrative sections of the Book of Mormon, but rarely in Hebrew poetic, literary, or prophetic writing (Parry, 1992). The presence of Hebraisms in the Book of Mormon keyness analysis demonstrates to Latterday Saints the historical origin of this sacred text. The word "pass" links Latter-day Saints to ancient Palestine and to God's ancient Abrahamic covenant people.

Additionally, this keyword may suggest the presence of a narrator's voice as well as continuity of worldview throughout the text.

The second keyword "land" refers to the geographical settings of the Book of Mormon. The lands of the Book of Mormon are frequently mentioned in the text and figure importantly in the historical narrative. An example of land in the text is when Lehi talks to his children about how they left the land of Jerusalem and have been led to a new land: "We have obtained a land of promise, a land which is choice above all other lands, a land which the Lord God hath covenanted with me" (2 Nephi 1:5). The presence of the keyword land demonstrates the connection of God's people to the earth and God's blessings through covenantal living with him. 
The keywords "people", "Lamanites", and "Nephites", along with the word "land", show that the Book of Mormon is about groups of people and civilizations. An example text including this focus is the following: "And now as ye are desirous to come into the fold of God and to be called his people" (Mosiah 18:8). These are narratives about how God's people throughout history worked their way to salvation. Like biblical narratives in Genesis and Exodus, these are stories of groups of people struggling to find and stay on the Lord's path. This level of focus in the Book of Mormon demonstrates to Latter-day Saints the importance of collectivist and communal relationships in the process of drawing closer to God.

RQ2 compared the New Testament to the Book of Mormon. The results suggest that the New Testament focuses on individuals and their activities such as talking to each other (e.g., "said" and "answered"). In contrast, the Book of Mormon seems to have a group and civilization level focus. One explanation for this is the context from which the writings emerged. The New Testament is largely a collection of individual eyewitness accounts and letters, written during the final years of the 2nd Temple period and the decades right after its destruction. The Book of Mormon consists of a curated record of writings that occurred over a longer period of time, including between $600 \mathrm{BCE}$ and 400 CE. The narrower focus of the New Testament may have prevented forming a more communal narrative. Note the focus in the individual in the story of the Rich Ruler from Luke 18:20-23:

Thou knowest the commandments, Do not commit adultery, Do not kill, Do not steal, Do not bear false witness, Honour thy father and thy mother. And he said, All these have I kept from my youth up. Now when Jesus heard these things, he said unto him, Yet lackest thou one thing: sell all that thou hast, and distribute unto the poor, and thou shalt have treasure in heaven: and come, follow me. And when he heard this, he was very sorrowful: for he was very rich.

The individual-based focus is not the only explanation for the differences encountered. Another explanation is a variation in soteriology. The writers of the New Testament emphasized the individual's role and responsibilities for their own salvation. In contrast, the writers of the Book of Mormon present a more communal understanding of soteriology. For example, King Benjamin invites his people as a whole to make a covenant with God to keep his commandments and if they do he will give them the name of Christ, which will be written in their hearts (Mosiah 5:7). Between the latter and the former, it appears that the former is more likely because the scope of the text does not necessarily reflect theological differences between the primitive New Testament church and the Book of Mormon Church of Christ. However, the more Christocentric focus of the New Testament (e.g., keyword "Jesus") may reflect foundational differences in views of salvation that have emerged since the texts were produced.

RQ3 identified the keywords of the Book of Mormon compared to the Hebrew Bible. Along with the results of RQ1, these results show that the Book of Mormon is 
about the Lamanites, Nephites, and persons named Nephi. However, words present in RQ1, which are not present here, are "land" and "people", suggesting that while the Hebrew Bible is not about the same specific civilizations, both the Book of Mormon and the Hebrew Bible focus on groups of people and their associated geographies. This focus on civilizations and kinship demonstrates common communal values within both of these sacred texts and link Latter-day Saints to ancient Israel.

Both RQ1 and RQ3 include the keywords "pass", "yea", and "behold". This suggests phrasing and language style differences between the Book of Mormon and the combined biblical texts. The word pass, as noted above, is part of a Hebrew expression used in narrative passages. While both the Hebrew Bible and Book of Mormon frequently use this phrase, the higher frequency in the Book of Mormon suggests higher portions of narrative text. The words yea and behold also suggest style distinctions between the Book of Mormon and biblical texts. While the translation of the Book of Mormon occurred within a KJV saturated religious discourse, and while the KJV Bible and the Book of Mormon both contain early modern and late middle English, these text distinctions suggest unique style aspects in the Book of Mormon compared to the language used by the King James translators. These findings demonstrate the Latter-day Saint view of the Book of Mormon as a unique scripture coming from God.

Also, regarding RQ3, the word "Christ" occurs in the Book of Mormon but not in the Hebrew Bible. The presence of Christ in the Book of Mormon and not in the Hebrew Bible is not unexpected but does demonstrate the strong Christ theme that is in the Book of Mormon. It is noted that while Christ is a keyword in the Book of Mormon compared to the Hebrew Bible, the word Jesus is a keyword in the New Testament compared to the Book of Mormon. This demonstrates the role of the Book of Mormon for Latter-day Saint communities in forming a Christocentric reading of all three texts. For example, in the Book of Mormon Abinadi refers to the Messiah who is recognized as Jesus Christ in the Hebrew Bible writings when he asks, "Did not Moses prophesy unto them concerning the coming of the Messiah and that God should redeem his people...and even all the prophets?" (Mosiah 13:33), following which Abinadi goes on to identify the Messiah as the suffering servant in Isaiah 53 (Mosiah 14). The keyword Christ in the Book of Mormon demonstrates how Latter-day Saints see these sacred texts as centralized in a faith in Jesus Christ.

RQ4 focused on keyness of the Hebrew Bible when the reference corpus is the Book of Mormon. The top three words "thy", "thee", and "thou" are all second-person singular pronouns. These words are used when individuals speak with each other, and these results may indicate that the Hebrew Bible has a greater focus on an individual level of dialogue than the Book of Mormon. An alternative explanation is that this corpus contains a greater level of theophany. For example, Ticciati (2013) talked about the role of first- and second-person pronouns in Job's development of an I-thou relationship with God in which "Job's identity is guaranteed by God" (p. 47). Job uses the second-person pronoun to speak directly to God and in return God uses the second-person pronoun to speak directly to Job, confirming his unique individuality. In another example, God 
speaks to Moses using the second-person pronoun, saying "I will be with thy mouth, and teach thee what thou shalt say" (Exodus 4:12, emphasis added). These pronouns may thus reflect Hebrew spirituality which is rooted in tangible interactions with God. A third explanation is that these findings reflect particular pronoun textual variations in the early modern and late middle English usage of the Hebrew Bible compared to the Book of Mormon as used by the KJV Hebrew Bible translators compared to the Book of Mormon translator, or that the Hebrew Bible uses archaic forms at different rates than the Book of Mormon. As well, if all pronouns had been lemmatized, different results may have been obtained. Taken together, the first two explanations appear to be the most likely explanation of the presence of thy, thee, and thou, because of the levels of one-on-one communication as well as the higher presence of dialogue related to theophany as compared to writings in the Book of Mormon. These findings demonstrate unique aspects of the Hebrew Bible as a text saturated with relationship and the development of the individual through interactions with deity. These results provide contrast with the RQ3 findings for the Book of Mormon which, by comparison, highlight the focus of how civilizations as well as individuals relate to a God who is active in the universe. In addition, the present study did not lemmatize given the goal of obtaining the most granular results possible. Future research may examine keyness after lemmatization to explore the broad influence of pronoun use in the Book of Mormon.

Along with thy, thee, and thou, the words "said" and "shalt" also appear to be associated with person-to-person dialogue as well as communication between humans and deity. It is also noted that "said" is a keyword of both the Hebrew Bible (RQ4) as well as the New Testament (RQ2), compared to the Book of Mormon. Sample text from the Hebrew Bible with these words occur with the decalogue: "And the Lord said unto Moses, Thus thou shalt say unto the children of Israel, Ye have seen that I have talked with you from heaven" (Exodus 20:22, emphasis added). These words further emphasize the focus of the Hebrew Bible on the individual in comparison to the Book of Mormon emphasis on the deity-civilization relationship. The RQ4 Hebrew Bible findings also include the keywords "Israel" and "David". These words highlight that the Hebrew Bible deals more with the House of Israel and Israel's king than does the Book of Mormon. While the Book of Mormon also talks about the nation and kingdom of Israel, the references are less frequent and less specific. This is because the Book of Mormon occurs in a setting that is removed in space and time from Palestine's Israel, and the Book of Mormon references to Israel and David are made historically rather than in present tense. To Latter-day Saints, the Book of Mormon does not give the history of the House of Israel, but it gives the context to the House of Israel through a global perspective. This perspective may reflect the Latter-day Saint view of the present involvement of the God of ancient Israel.

The word "Lord" in the Hebrew Bible refers to YHWH, or Yahweh, the Hebrew name of God that was revealed to Moses. It is noted that "God", as a possible synonym to "Lord", does not show up in this keyness list. In comparison to the keyword Lord, it is again noted that the word Christ is a keyword of the Book of Mormon compared to the Hebrew Bible (RQ3), and that Jesus is a keyword of the New Testament compared to the Book of Mormon (RQ2). These results highlight variations in how these texts 
conceptualize and refer to deity. For Latter-day Saints, Yahweh or Jehovah, Jesus, and Christ are all the same being. These results highlight Latter-day Saint cosmology.

RQ5 examined the collocates of "God" in the Book of Mormon. The goal was to capture the "aboutness" of God from a Latter-day Saint worldview. The strongest collocate of God is the word "God". Self-collocation has been referred to as "burstiness" (Church and Gale, 1995), and it means that when a word occurs, it tends to occur more than once, or in groups with itself. While it is already known that a major theme in the Book of Mormon is deity, these burstiness findings further suggest that God is one of main things that the book is about. The following text demonstrates the self-referencing tendency of God in the Book of Mormon:

Therefore lift up your heads and rejoice and put your trust in God, in that God who was the God of Abraham and Isaac and Jacob, and also that God who brought the children of Israel out of the land of Egypt and caused that they should walk through the Red Sea on dry ground and fed them with manna that they might not perish in the wilderness; and many more things did he do for them. (Mosiah 7:19, emphasis added)

In this passage King Limhi uses references to God in the past to help his people understand who God is to them now, specifically as a helper and a deliverer. These findings show the importance of God in the text as a being one who is peerless and compared only to himself. Self-collocation of deity reflects how the Book of Mormon text and Latter-day Saint worldview revolve around a common theocentric perspective.

The second strongest collocate was "commandments". This collocate indicates an understanding of God in the Book of Mormon as a rule-giving agent. In the Book of Mormon, the word "commandments" is often associated with God, and the phrase "commandments of God" occurs frequently. An example of this phrase in the text is the following: "And this was their faith, that by so doing God would prosper them in the land; or in other words, if they were faithful in keeping the commandments of God, that he would prosper them in the land" (Alma 48:15). Latter-day Saints see God as a caring father in whom they can trust for personal help as well as instruction.

The third strongest collocate was "word". This word has special meaning in the Bible, including in the famous opening of the Gospel of St. John, "In the beginning was the Word, and the Word was with God, and the Word was God" (John 1:1). In this scripture word refers to Jesus Christ but also implies the "In the beginning" (Genesis 1:1) of when God spoke and by his word brought into being or organized all of creation. In the Bible, word has the Greek root of logos, meaning reason, understanding, or truth; and the associated Hebrew association is dabar, which may be called "performative utterances" or "a divine command to lead a sacrificial life of service" (Berman, 1994, p. 145). Like the biblical texts, word in the Book of Mormon is frequently associated with God and refers to a way of spiritual living. An example from the Book of Mormon is, "They did impart the word of God one with another without money and without price" 
(Alma 1:20). Word as a collocate of God signifies to Latter-day Saints the association of God's voice and words to him and connects Latter-day Saints to a righteous way of living that is tied to God.

Taken together, the top collocations suggest a view of God as presented in the Book of Mormon. This God is a being who is self-defined and compares only to himself, gives instructions to guide his children, and speaks words from himself that can be used by humankind and individuals. The self-referencing of the word God brings to mind Yahweh, who told Moses that his name is "I am that I am" (Exodus 3:14), and of the New Testament Jesus who referred to himself him the same way, saying "Verily, verily, I say unto you, Before Abraham was, I am" (John 8:58). As well, this Book of Mormon God is a personal God who exists within the cosmos, interacting personally with humanity through his commandments and words. These collocates of deity present an allpowerful and involved God in whom Latter-day Saints can trust, believe, and find meaning.

The combined keyness and collocation findings paint a picture of the worldview presented in the Book of Mormon. The keyness results present an overall Book of Mormon view of God interacting with groups of people and civilizations over periods of time, and has less individual focus than that present in the New Testament and Hebrew Bible. The Book of Mormon is about a larger picture view of humanity, whereas the New Testament is about a relatively small set of people talking to each other. The Hebrew Bible is also about lands and groups of people but doesn't talk about Jesus Christ, which the Book of Mormon does, and also has more theophany. These keyness results, combined with the collocation findings regarding the view of God, suggest a Book of Mormon worldview in which Christocentric and other spiritual perspectives are encompassed in an overall theistic view of the world.

When considering limitations, two should be kept in mind. The first limitation is related to the keyness study, which used English language comparison. While the Book of Mormon was originally published in English, the text itself has references to its Reformed Egyptian, Hebrew, and other language origins. The Hebrew Bible and New Testament original languages were Hebrew, Greek, and Aramaic. While it is necessary for the texts to be in the same language to have a keyness analysis, some results may be due to translation word choices and may not be due to differences in the original language constructs. I purposely chose editions and translations of the corpuses that have similar uses of English language to reduce noise due to language differences. However, keyness analysis with different versions or languages would produce different results.

The second limitation is related to collocation and the minimum number of times a word needed to occur in the text to be included. I chose a large number (100) to allow major collocation themes to emerge. However, this criterion eliminated many less frequently occurring but significant collocates. For example, setting this number at three would have produced the top two collocates of "Isaac" $\left(\mathrm{MI}^{2}=8.216\right)$ and "changeable" $\left(\mathrm{MI}^{2}=8.069\right)$, suggesting the association of God to the biblical patriarch and to the trait 
of not changing. Or, if I had set the minimal cutoff value to 40 , the second collocate after God would have been "lamb" $\left(\mathrm{MI}^{2}=6.368\right)$, also a significant result. Future research may explore a more nuanced examination of the less frequently occurring collocates of God in the Book of Mormon.

The obtained results suggest some implications for further research. First, while I compared the Book of Mormon to other monotheistic sacred texts, it could also be profitably compared to sacred texts beyond the Hebrew Bible and New Testament. For example, it may be useful to compare it to the Tripitaka, Vedic and Tantric texts, or to the Quran. There are also implications for further research regarding the collocation analysis and for corpus linguistics generally. As mentioned, analysis of lower frequency terms that collocate with "God" may provide more nuanced results, and collocation analysis of other terms may be useful as well. Further, there currently is little application of corpus linguistic tools for Latter-day Saint religious texts, and it is hoped that this research will inspire researchers to consider new applications of corpus linguistics tools for Latter-day Saint and other religious documents.

The findings of this research suggest key implications for mental health professionals both familiar and unfamiliar with members of The Church of Jesus Christ of Latter-day Saints and related Latter-day Saint communities. For those who are not familiar with this population, the keyness and collocation results may generally present an understanding of the spiritual worldview of Latter-day Saint clients, and understanding this multicultural diversity will help professionals attune to these individuals. For those who are familiar with the Latter-day Saint population, these findings also have implications for practice. These findings highlight aspects of Latter-day Saint theology and spirituality that may not be readily apparent or that may be underappreciated. The following are several implications for mental health professionals.

The first implication of this research is the theocentric worldview of Latter-day Saints which is present in the Book of Mormon. The keyness and collocation results present a worldview that is rooted in God and his involvement in humankind throughout history, which may be called theocentric rather than Christocentric, in which Christology is centered within a larger theocentric perspective. This is a nuance that distinguishes Latter-day Saints from non-Latter-day Saint Christians, and this view is also distinct from non-religious clients. Understanding this individual and cultural background puts mental health professionals in a position to assess for spirituality and how religious and spiritual views inform presenting concerns. Latter-day Saints are less concerned with their relationship with Jesus, or with "What would Jesus do?" and are more concerned with their relationship with God, and their place within Latter-day Saint cosmology, which spans from preexistence to post-final judgment and post-mortality, compared to other Christians. For example, a distressed Latter-day Saint client may find comfort and meaning in exploration of their connection or lack of connection to God and God's purpose for them in their lives. Exploring such spiritual ruptures as attachment injuries may be empowering to Latter-day Saint clients. 
A second implication of these findings for mental health professionals is the need of Latter-day Saint clients to find identity and personal meaning within the grand Latterday Saint worldview and narrative. While the keyness results highlight ways in which the Book of Mormon is about groups and civilizations relating to God, the individual and Ithou relationships within the New Testament and Hebrew Bible are also part of the Latter-day Saint scriptural cannon. These scriptures have meaning to members of The Church of Jesus Christ of Latter-day Saints, and it appears that within Latter-day Saint theology and spirituality the theocentric view needs to be rooted within a personal relationship with God. For example, when Job was suffering, it can be seen that his friends pushed a theology that made Job invisible, pushing platitudes that urged him to not complain or speak to God. However, he persevered and upheld a theology rooted in personal identity with God (Ticciati, 2013). The results similarly highlight the role of the individual in the New Testament. In this way, these biblical texts compliment the Book of Mormon findings of this research. For example, to fully flesh out the theocentric worldview, a Latter-day Saint client may find utility in considering how their presenting concerns fit into the overall context of their spiritual life purpose. Or when client emotions arise, especially if affect appears to be blocked, considering how feelings fit into or conflict with the theocentric worldview may put the mental health professional into a position to understand the meaning of those emotions to the client. When anger or hurt arises, the mental health professional may ask the client whether they believe it is okay to be angry toward a parent, parent figure, or at God himself, and then explore ways to find meaning for affect within the spiritual theocentric view. Such approaches can strengthen alliance and deepen therapeutic work.

A third implication is the need for connecting with others in the path toward God. Within the Book of Mormon narrative are imbedded communal and collectivist values. In a study of religion in the U.S., the Pew Research Center found that among all Christian religions, Latter-day Saint members are one of the most highly involved in their congregations (Sandstrom, 2016). Latter-day Saints need to not only connect with deity, but members of the Latter-day Saint church have spiritual needs and values in regard to identity within a communal belonging. Keeping in mind ways in which Latter-day Saint clients relate to or are disconnected from others of their faith community may facilitate therapeutic work in counseling.

Fourthly, this research points mental health professionals toward the spirituality of Latter-day Saints. Most of those who join the Latter-day Saint Church of Jesus Christ have done so to get closer to God, to find happiness and a sense of peace, or to find a better sense of purposefulness and direction in their lives (Anderson, 1977). However, often counseling can be secularized by humanistic and cognitive-behavioral approaches, and when clients do address their religion, often they approach it from historical, political, and cognitive rather than spiritual perspectives. While religious clients have often been socialized to secularize their presenting problems, doing so may not be in their interest. The findings of this study point mental health professionals to the spiritual roots of the Latter-day Saint client and community. For example, the collocation results highlight a view of God as a self-defined individual who speaks to humans to give us 
direction. This view of God implies a spiritual identity of the Latter-day Saint client that occurs in a relationship with God, which may be positively internalized. Even those who have left the Church of Jesus Christ of Latter-day Saints may retain a portable theocentric worldview rooted in the Book of Mormon. In a counseling setting, assessing how spiritual identity intersects with mental health constitutes multiculturally competent counseling and may lead to empowerment of Latter-day Saint clients.

A fifth implication is regarding consideration of how the worldview of the mental health professional impacts clinical work. Latter-day Saint professionals with a theocentric spirituality need to be aware of their subjectivity when working with religious clients with a Christocentric or pneumocentric spirituality or when working with nonreligious clients with an anthropocentric worldview. As well, non-Latter-day Saint professionals need to be aware of their Christocentrism, pneumocentrism, or anthropocentricism to allow attunement to the theocentricism of Latter-day Saint clients.

Finally, the keyness and collocation results highlight the importance of the Book of Mormon as a significant and unique sacred text for informing professional understanding of Latter-day Saint clients. While some scholars have described the Book of Mormon as having added little new theology that distinguishes it from protestant Christian faiths (Givens, 2015), this corpus linguistic analysis sheds new light on the Book of Mormon, such as having less theophany than the Hebrew Bible, less focus on individuals than the Hebrew Bible or the New Testament, but a broader view of God than either of the biblical texts. Even mental health professionals familiar with the Latter-day Saint faith may gain from this research an appreciation of the Book of Mormon as a document that undergirds the Latter-day Saint worldview, the cognitive awareness of which can inform spiritually integrated and culturally informed practice. This research highlights this unique way in which mental health professionals can view

the Book of Mormon as a document to inform the understanding of the Latter-day Saint spiritual worldview.

\section{References}

American Counseling Association. (2014). ACA code of ethics. https://www.counseling.org/resources/aca-code-of-ethics.pdf

Benoit, K., Watanabe, K., Wang, H., Lua, J. W., \& Kuha, J. (2021). Package 'quanteda. textstats'. Research Bulletin, 27(2), 37-54. https://cran.rproject.org/web/packages/quanteda.textstats/quanteda.textstats.pdf

Benoit, K., Watanabe, K., Wang, H., Nulty, P., Obeng, A., Müller, S., Matsuo, A., \& Lowe, W. (2021). Package 'quanteda'. https://cran.rproject.org/web/packages/quanteda/quanteda.pdf

Berman, H. J. (1994). Law and logos. DePaul Law Review, 44(1), 143-165.

Boers, F., Demecheleer, M., He, L., Deconinck, J., Stengers, H., \& Eyckmans, J. (2017). Typographic enhancement of multiword units in second language text. International Journal of Applied Linguistics, 27(2), 448-469. https://doi.org/10.1111/ijal.12141 
Brezina, V. (2018). Statistics in corpus linguistics: A practical guide. Cambridge University Press.

Brezina, V., McEnery, T., \& Wattam, S. (2015). Collocations in context: A new perspective on collocation networks. International Journal of Corpus Linguistics, 20(2), 139-173. https://doi.org/10.1075/ijcl.20.2.01bre

Bullock, C. H. (1997). God. In W. A. Elwell (Ed.), Baker's evangelical dictionary of biblical theology. Baker Books.

https://www.biblestudytools.com/dictionaries/bakers-evangelicaldictionary/god.html

Callister, P. (2020). The Book of Mormon authorship and theology of God: A corpus linguistic research project. https://osf.io/e59z8/

Church, K. W., \& Gale, W. A. (1995). Poisson mixtures. Natural Language Engineering, 1(2), 163-190. https://doi.org/10.1017/S1351324900000139

The Church of Jesus Christ of Latter-day Saints. (n.d.-a). Facts and statistics: United States. https://newsroom.churchofjesuschrist.org/facts-andstatistics/country/united-states.

The Church of Jesus Christ of Latter-day Saints. (n.d.-b). God. Bible dictionary. https://www.churchofjesuschrist.org/study/scriptures/bd/god?lang=eng

Cohen J. (1988). Statistical power analysis for the behavioral sciences. LEA.

Dunning, T. E. (1993). Accurate methods for the statistics of surprise and coincidence. Computational Linguistics, 19(1), 61-74. https://dl.acm.org/doi/10.5555/972450.972454

Ellis, P. D. (2009). Effect size calculators. http://www.polyu.edu.hk/mm/effectsizefaqs/calculator/calculator.html

Faul, F., Erdfelder, E., Buchner, A., \& Lang, A.-G. (2009). Statistical power analyses using $\mathrm{G}^{*}$ Power 3.1: Tests for correlation and regression analyses. Behavior Research Methods, 41, 1149-1160. https://doi.org/10.3758/BRM.41.4.1149

Feinerer, I. (2011). tm: Text mining package. R package version 0.5-5 [software]. https://cran.r-project.org/package $=$ tm

Firth, J. R. (1957). Papers in linguistics 1934-1951. Oxford University Press.

Freud, S., Strachey, J., \& Gay, P., (1989). New introductory lectures on psycho-analysis. W. W. Norton.

Gabrielatos, C. (2018). Keyness analysis: nature, metrics and techniques. In C. Taylor \& A. Marchi (Eds.), Corpus approaches to discourse: A critical review (pp. 225258). Routledge.

Givens. T. L. (2015). Wrestling the angel: The foundations of Mormon thought: Cosmos, God, humanity. Oxford. https://doi.org/10.1093/acprof:oso/9780199794928.001.0001

Hall, G. C. N., Berkman, E. T., Zane, N. W., Leong, F. T. L., Hwang, W.-C., Nezu, A. M., Nezu, C. M., Hong, J. J., Chu, J. P., \& Huang, E. R. (2020). Reducing mental health disparities by increasing the personal relevance of interventions. American Psychologist. Advance online publication. https://doi.org/10.1037/amp0000616 
Knight, M. (2010). Wirkungsgeschichte, Reception history, reception theory. Journal for the Study of the New Testament, 33(2), 137-146.

https://doi.org/10.1177/0142064X10385858

National Association of Social Workers. (2017). NASW code of ethics. https://www.socialworkers.org/About/Ethics/Code-of-Ethics/Code-of-EthicsEnglish

Neath, A. A., \& Cavanaugh, J. E. (2012). The Bayesian information criterion: Background, derivation, and applications. Wiley Interdisciplinary Reviews: Computational Statistics, 4(2), 199-203. https://doi.org/10.1002/wics.199

Oxford University Press. (2020). World-view. Oxford English dictionary online. www.oed.com/view/Entry/230262

Parry, D. W. (1992). Why is the phrase "and it came to pass" so prevalent in the Book of Mormon? Ensign (12). The Church of Jesus Christ of Latter-day Saints. https://www.churchofjesuschrist.org/study/ensign/1992/12/i-have-aquestion/why-is-the-phrase-and-it-came-to-pass-so-prevalent-in-the-book-ofmormon?lang=eng

Richards, W. (1844). Remarks, 28 November 1844. The Joseph Smith Papers. https://www.josephsmithpapers.org/paper-summary/discourse-7-april-1844-asreported-by-willard-richards $/ 1$

Sandstrom, A. (2016). 6 facts about U.S. Mormons. The Pew Research Center. https://www.pewresearch.org/fact-tank/2016/09/30/6-facts-about-u-s-mormons/

Scott, M. (2020). WordSmith tools version 8 [Computer software]. Lexical Analysis Software.

Skousen, R. (Ed.). (2009). The Book of Mormon: The earliest text. Yale University Press.

Smith, J. (1835). Revelation, circa June 1835 [D\&C 68]. The Joseph Smith papers. https://www.josephsmithpapers.org/paper-summary/revelation-circa-june-1835dc- $68 / 1$

Smith, J. (1842). Times and seasons, 15 April 1842. The Joseph Smith papers. https://www.josephsmithpapers.org/paper-summary/times-and-seasons-15-april$\underline{1842 / 9}$

Sue, D. W., \& Sue, D. (2013). Counseling the culturally diverse: Theory and practice (6th ed.). John Wiley.

Pew Research Center. (2019). In U.S., decline of Christianity continues at rapid pace: An update on America's changing religious landscape.

https://www.pewforum.org/2019/10/17/in-u-s-decline-of-christianity-continuesat-rapid-pace/\#fn-32175-4

Ticciati, S. (2013). Theology in the second person: Job's indexical spirituality. In A. T. Lincoln, J. G. McConville, \& L. K. Pietersen (Eds.), The Bible and spirituality: Exploratory essays in reading scripture spiritually (pp. 38-55). Cascade Books.

Tillich, P. (1957). Systematic theology, Volume II: Existence and the Christ. University of Chicago Press.

Von Humboldt, W. (2000). Humboldt: 'On language' on the diversity of human language construction and its influence on the mental development of the human species (M. Losonsky, Ed.; P. Heath, Trans; 2nd ed.). Cambridge University Press. (Original work published in 1836). 
Wang, S. P. (2014). Using technological tools to analyze biblical texts metaphorical repetition in the Book of Matthew. European Journal of Science and Theology, 10(5), 147-158.

Weisser, M. (2016). Practical corpus linguistics: An introduction to corpus-based language analysis. Wiley-Blackwell. 
Table 1

Top Eight Words with Strong Keyness

\begin{tabular}{|c|c|c|c|c|c|c|}
\hline Study & Ref. & Token & Study Ct. & Ref. Ct. & $G^{2 *}$ & $\mathrm{BIC}^{* *}$ \\
\hline BoM & NT & pass & 1571 & 118 & 972.13 & 959.11 \\
\hline BoM & $\mathrm{NT}$ & land & 1252 & 50 & 951.80 & 938.78 \\
\hline BoM & $\mathrm{NT}$ & yea & 1254 & 65 & 887.15 & 874.14 \\
\hline BoM & $\mathrm{NT}$ & people & 1770 & 231 & 806.63 & 793.62 \\
\hline BoM & NT & behold & 1640 & 222 & 727.57 & 714.55 \\
\hline BoM & $\mathrm{NT}$ & lamanites & 701 & 0 & 718.71 & 705.69 \\
\hline BoM & $\mathrm{NT}$ & nephi & 474 & 0 & 485.81 & 472.80 \\
\hline BoM & $\mathrm{NT}$ & nephites & 375 & 0 & 384.29 & 371.27 \\
\hline NT & BoM & jesus & 983 & 190 & 955.57 & 942.55 \\
\hline $\mathrm{NT}$ & BoM & said & 1061 & 386 & 659.24 & 646.23 \\
\hline $\mathrm{NT}$ & BoM & man & 869 & 469 & 337.13 & 324.11 \\
\hline $\mathrm{NT}$ & BoM & paul & 170 & 0 & 310.98 & 297.96 \\
\hline $\mathrm{NT}$ & BoM & peter & 160 & 1 & 281.55 & 268.53 \\
\hline $\mathrm{NT}$ & BoM & disciples & 243 & 54 & 218.20 & 205.18 \\
\hline $\mathrm{NT}$ & BoM & answered & 203 & 32 & 217.08 & 204.07 \\
\hline $\mathrm{NT}$ & BoM & john & 136 & 4 & 216.54 & 203.52 \\
\hline BoM & $\mathrm{HB}$ & yea & 1254 & 275 & 1725.65 & 1711.97 \\
\hline BoM & $\mathrm{HB}$ & lamanites & 701 & 0 & 1656.77 & 1643.08 \\
\hline BoM & $\mathrm{HB}$ & pass & 1571 & 712 & 1402.85 & 1389.16 \\
\hline BoM & $\mathrm{HB}$ & nephi & 474 & 0 & 1119.99 & 1106.31 \\
\hline BoM & $\mathrm{HB}$ & behold & 1640 & 1104 & 987.70 & 974.01 \\
\hline BoM & $\mathrm{HB}$ & christ & 390 & 0 & 921.43 & 907.74 \\
\hline BoM & $\mathrm{HB}$ & nephites & 375 & 0 & 885.98 & 872.29 \\
\hline BoM & $\mathrm{HB}$ & things & 914 & 433 & 785.77 & 772.08 \\
\hline $\mathrm{HB}$ & BoM & thy & 4184 & 468 & 1142.43 & 1128.75 \\
\hline $\mathrm{HB}$ & BoM & thee & 3343 & 294 & 1107.56 & 1093.88 \\
\hline $\mathrm{HB}$ & BoM & thou & 4617 & 611 & 1064.09 & 1050.41 \\
\hline $\mathrm{HB}$ & BoM & israel & 2490 & 213 & 840.41 & 826.73 \\
\hline $\mathrm{HB}$ & BoM & lord & 7119 & 1575 & 720.96 & 707.27 \\
\hline $\mathrm{HB}$ & BoM & said & 2938 & 386 & 681.35 & 667.66 \\
\hline $\mathrm{HB}$ & BoM & david & 953 & 8 & 625.84 & 612.15 \\
\hline $\mathrm{HB}$ & BoM & shalt & 1509 & 104 & 581.96 & 568.27 \\
\hline
\end{tabular}

$* p<0.001 ;$ critical value $=10.83$

$* *>10$ : very strong evidence against $\mathrm{H}_{0}$

Note. $\mathrm{BoM}=$ Book of Mormon, $n=270,011 ; \mathrm{NT}=$ New Testament, $n=180,585 ; \mathrm{HB}=$ Hebrew Bible, $n=609,424$. 
Table 2

Collocation Outputs for the Node word God (RQ5)

\begin{tabular}{|c|c|c|c|c|c|c|}
\hline $\mathrm{N}$ & Token & $\begin{array}{l}\text { Raw Count } \\
\text { in } 8 \mathrm{R} 8 \mathrm{~L} \\
\text { Window of } \\
\text { Node }\end{array}$ & $\begin{array}{l}\text { Raw } \\
\text { Count in } \\
\text { Corpus }\end{array}$ & $\begin{array}{l}\text { Observed } \\
\text { Proportion }\end{array}$ & $\begin{array}{l}\text { Expected } \\
\text { Proportion }\end{array}$ & $\mathrm{MI}^{2}$ \\
\hline 1 & God & 1852 & 1676 & 1.105 & 0.006 & 7.476 \\
\hline 2 & commandments & 91 & 210 & 0.054 & 0.001 & 6.125 \\
\hline 3 & word & 126 & 317 & 0.075 & 0.001 & 6.001 \\
\hline 4 & kingdom & 46 & 151 & 0.027 & 0.001 & 5.617 \\
\hline 5 & power & 113 & 413 & 0.067 & 0.002 & 5.462 \\
\hline 6 & keер & 41 & 155 & 0.024 & 0.001 & 5.413 \\
\hline 7 & church & 58 & 226 & 0.035 & 0.001 & 5.37 \\
\hline 8 & son & 85 & 340 & 0.051 & 0.001 & 5.332 \\
\hline 9 & true & 26 & 107 & 0.016 & 0 & 5.291 \\
\hline 10 & holy & 70 & 298 & 0.042 & 0.001 & 5.242 \\
\hline 11 & cometh & 31 & 132 & 0.018 & 0 & 5.242 \\
\hline 12 & $a m$ & 43 & 194 & 0.026 & 0.001 & 5.158 \\
\hline 13 & jacob & 22 & 101 & 0.013 & 0 & 5.133 \\
\hline 14 & cry & 25 & 115 & 0.015 & 0 & 5.13 \\
\hline 15 & remember & 33 & 161 & 0.02 & 0.001 & 5.045 \\
\hline 16 & before & 89 & 436 & 0.053 & 0.002 & 5.039 \\
\hline 17 & stand & 22 & 108 & 0.013 & 0 & 5.036 \\
\hline 18 & christ & 75 & 390 & 0.045 & 0.001 & 4.953 \\
\hline 19 & known & 21 & 110 & 0.013 & 0 & 4.943 \\
\hline 20 & jesus & 36 & 190 & 0.021 & 0.001 & 4.932 \\
\hline 21 & who & 58 & 308 & 0.035 & 0.001 & 4.923 \\
\hline 22 & knowledge & 24 & 128 & 0.014 & 0 & 4.917 \\
\hline 23 & lord & 289 & 1575 & 0.172 & 0.006 & 4.886 \\
\hline 24 & $i s$ & 264 & 1452 & 0.158 & 0.005 & 4.872 \\
\hline 25 & deliver & 21 & 117 & 0.013 & 0 & 4.854 \\
\hline
\end{tabular}

